Xinchun Li, Li Liu

\title{
Embedded Guanxi Networks, Market Guanxi Networks and Entrepreneurial Growth in the Chinese Context
}

\author{
(C) Higher Education Press and Springer-Verlag 2010
}

\begin{abstract}
Entrepreneurial networks create an important entrepreneurial opportunity and facilitate resource acquisition. However, there has been little research on the correlation between the types of guanxi networks and entrepreneurial growth. This paper divides entrepreneurial/managerial networks into embedded guanxi networks based on social relationship and non-economic trade contracts, and market guanxi networks based on market negotiation. Hypotheses are proposed on how the embedded/market guanxi networks evolve with enterprise age and size. Data from 270 Chinese enterprises are used to empirically test the above classification and hypotheses. The results justify the new dichotomy for guanxi networks. It is also shown that, as an enterprise grows in age and size, its utilization of embedded guanxi network tends to decrease while its reliance on market guanxi network increases. In addition, as an enterprise grows in size and age, the impact of embedded guanxi network on enterprise performance remains significant, while the impact of market guanxi network keeps increasing.
\end{abstract}

Keywords entrepreneurial growth, entrepreneurial networks, embedded guanxi network, market guanxi network

Translated from Zhongshan Daxue Xuebao (Shehui Kexueban) 中山大学学报 (社会科学 版) (Journal of Sun Yat-sen University (Social Science Edition)), 2009, 49(3): 190-202

Xinchun Li

School of Business, Sun Yat-sen University, Guangzhou 510275, China

E-mail: mnslxc@mail.sysu.edu.cn

Li Liu $(\bowtie)$

School of Business, Sun Yat-sen University, Guangzhou 510275, China

E-mail: lilyrock@263.net 


\section{Introduction}

The extant research on strategic management indicates that networks are critical to enterprise growth and development. Relevant literature can be grouped into two streams: One of them focuses on the inter-enterprise network (e.g., strategic alliance, alliance keiretsu, and alliance groups) and the other highlights the personal network, i.e., interpersonal connections among entrepreneurs or senior managers.

guanxi (The interpersonal connection) based on informal contracts plays an important role in enterprise performance and regional economic growth, especially in East Asia. Among the eastern Asian countries, China's guanxi networks are centered on informal personal connections, exhibiting a unique feature characterized by significant "embeddedness" in the traditional Chinese culture such as "personal favor" (renqing), "reciprocity," "responsibility" and "obligation." Current research on strategic management mostly focuses on describing the significance of entrepreneurs' interpersonal connections, or the correlation between the enterprise's performance and the connections between the entrepreneurs and senior managers. Based on data from Chinese enterprises, some researchers have found that a significant positive correlation does exist between enterprise performance and their entrepreneurs' social networks, while others denied the significant correlation. Research has been carried out to explain such conflicting conclusions from the perspective of contingency theory. However, we assume that such conflicting conclusions might be caused by confusion over the nature of guanxi networks and the existence of different types. In particular, different guanxi networks may have varying impacts on enterprise performance at different development stages and in various scenarios. In other words, the correlation between the guanxi network and the enterprise performance is by its nature dynamic and complex. Without an explicit separation of the different types and in-depth analysis on the factors involved, it would be difficult to gain a proper understanding of the correlation relationship. Therefore, this paper aims to explore the correlation in a comprehensive way.

In this research, we first divide entrepreneurs' guanxi into "embedded guanxi" and "market guanxi," then conduct an empirical study on this correlation between different guanxi networks, based on assumptions made in Chinese business scenarios. The fundamental idea of this paper is segmenting these two functions as the "embedded guanxi" and "market guanxi" in accordance with their different functions in acquiring and integrating resources as well as the difference in the function mechanisms of the two types of guanxi. By doing so, we hope to help entrepreneurs or managers better distinguish and utilize the two different types of "guanxi" as their enterprises move along different development stages. 
The remaining parts of this paper are organized as follows: Section 2 introduces the theory of entrepreneurs' relationship, and develops hypotheses. Section 3 describes the research method for empirical study, and presents its results. Section 4 concludes this paper.

\section{Theory and Hypotheses}

Recently, the entrepreneurial guanxi network in a transitional economy like China has drawn considerable attention from researchers in the field of enterprise strategy and entrepreneurship (Peng and Luo, 2000; Luo, 2003; Li and Zhang, 2007; Li, Poppo and Zhou, 2008). Peng et al. (1996, 2000, 2003) even coined a term "network-based strategy" to embody the importance of entrepreneurial guanxi network to enterprise strategy selection in a transitional economy. Redding (1990) and Zucker (1986) pointed out that in the context of an unstable legal and business environment, the informal, personal relationship between managers and their key stakeholders such as alliance partners or government officials are particularly important to enterprises. These informal and personal "guanxi" are thought to be one of the most important sources of competitive advantage. Peng and Luo (2000) and Luo (2003) proved that the utilization of entrepreneurial guanxi has a positive impact on enterprise performance, and the impact varies with different ownership structures, business sectors, enterprise sizes, industry growth rates, and previous strategies adopted. Li et al. (2008) found that, compared to domestic enterprises, there is an "inverted U" shaped relationship between the entrepreneur social networks of foreign-invested enterprises and enterprise performance. They conducted a survey based on 280 foreign-invested enterprises, and results showed that when there is a high degree of industrial competition and uncertainty, the impact ceases to be significant. However, Li and Gima (2001) found no significant impact of entrepreneur social network on enterprise performance after controlling environment factors. The above conflicting conclusions indicate that when studying the relationship between entrepreneur social network and enterprise performance, we need to take into consideration both contingency factors and the uniqueness of guanxi under the Chinese context.

None of the extant studies distinguished different types of guanxi. In addition, when measuring different social networks, they assumed that these networks are homogeneous in nature. We believe such a "coarse" definition of entrepreneur social network makes it difficult to distinguish the impacts of different entrepreneur social networks on enterprise performance at various enterprise development stages.

To further explore the problem and gain a deeper understanding of these might-be-different impacts, we believe that a classification of different guanxi 
networks into social-tie-based guanxi (referred to as embedded guanxi network) and market-transaction-based guanxi (referred to as market guanxi network) might help us to identify different impacts different guanxi might have on enterprise strategy and entrepreneurship.

\subsection{Embedded Guanxi and Market Guanxi Networks}

Social embeddedness is defined as the degree to which commercial transactions take place through social relations and networks of relations that use exchange protocols associated with social, noncommercial attachments to govern business dealings (Uzzi, 1999). Embeddedness exists when the social relationship of a tie influences the economic behaviors of an enterprise (Granovetter, 1985; Uzzi, 1996, 1997). In addition, the interaction among different "ties" is not exclusively economically motivated (Granovetter, 1992; Portes and Sensenbrenner, 1993), but grounded more amidst personal relationships, social capital, or the history of dyadic interactions (Hite, 1999). In contrast, the market ties are primarily motivated by expected economic benefits (Hirschman, 1982). The definition of the two ties shows that they are not culture-specific and therefore can be used to study the interpersonal relationship in Chinese society (He, 1996). Therefore, it is appropriate to observe and study the personal relationship in the Chinese context from the perspectives of embeddedness and market.

As a guanxi network could be based on social contracts, such as kinship, or friendship among friends or classmates, it is therefore belongs to the type of "social embedded network." Guanxi network could also be based on market transaction through the negotiation and contract endorsement and implementation. This kind of guanxi networks are referred to as market guanxi in this article. One should note that although part of market guanxi could be converted into embedded guanxi under certain circumstances, the differences between the two types of guanxi networks are obvious. In reality, the two types of guanxi exert differentiated impact on enterprises' strategy and resource choices. For example, newly-established enterprises, embedded guanxi network will help them gain access to more opportunities and resources, as these enterprises are at a disadvantageous position in terms of market guanxi networks.

Entrepreneurial guanxi networks are based on an entrepreneur's personnel guanxi network consisting of family members, relatives, friends and acquaintances (in the order of intimacy) (Yang, 1994). Compared with family or relative guanxi network, guanxi with friends or acquaintances are called "shuren" guanxi. Among these networks, the extant literature on entrepreneurial guanxi network pays much attention to the family or blood relationship. When tracing back to the final controller of enterprises, it has been found that most big companies in the world are actually controlled by families (Shanker and 
Astrachan, 1996). Aldrich (1999) and Aldrich and Zimmer (1986) found that at the early stage of their development, these companies were all closely connected with other families or family guanxi networks. And these strong ties among families (or family members) played important roles in acquiring needed resources like finance, talents and market resources. Data shows the enterprises set up by couples or family members/relatives account for more than a quarter of new enterprises (Ruef et al., 2002). The particular blood relationship is positively related to the entrepreneurial opportunity recognition (Barney, Clark \& Alvarez, 2003). Typically, when a Chinese entrepreneur creates an enterprise, the first question he/she has to consider is how to collect all the resources to ensure enterprise survival and development. So he/she would call for help from other family members, and invite them to be his/her partners (Hwang, 2006). The family system is one of the Chinese particular guanxi systems and the basis of other guanxi network. To a certain degree, other social relationships can be regarded as pan-family guanxi. Hamilton (1991) proved that the non-relative relationship plays important roles in Chinese business system. However, under the context of undeveloped legal and regulatory environment, although expanded business network help enterprises gain important access to information and customers, executives tend to be reluctant to develop business relationships with those they do not personally trust.

Based on the above rationale, family guanxi and shuren Guanxi are highly correlated in the Chinese informal social networks, constituting the embedded guanxi networks, and the stranger guanxi network belongs to, apparently, market guanxi. Considering the aim of this study, we define the embedded guanxi as the guanxi characterized by the responsibility, favor, reciprocity, and mianzi (face-saving), and market guanxi as an interest-based trading or cooperative relationship. We hence propose:

H1 In an entrepreneurial guanxi network, family guanxi and shuren guanxi constitute the main part of embedded guanxi network, and stranger guanxi constitutes the main part of market guanxi network.

\subsection{Evolution of Embedded Guanxi and Market Guanxi Networks}

The dynamic process of developing favorable relationships with important people is an important aspect in Chinese people's daily life (Huang, 1988; Yeung and Tung, 1996). Thus, stranger guanxi could be converted into shuren guanxi. The evolution of guanxi networks is a dynamic process. Many Western researchers have found that changes in social network structure are always embodied in a market guanxi network being converted into an embedded guanxi network (e.g., Hite, 1999; Larson and Starr, 1993). In a broader sense, the evolution process of entrepreneurial informal guanxi networks can be examined 
from the perspectives of embedded guanxi and market guanxi networks.

As above, at the early growth stage, a firm's development depends mostly on embedded guanxi networks, which are deeply rooted in existing social, familial or historically-accumulated relationships (Aldrich, 1999; Coleman, 1990; Larson and Starr, 1993; Walker et al., 1997). Under this circumstance, the financial resources are mostly acquired from the family members or friends, for the banks or VCs are reluctant to offer funds to new enterprises. Furthermore, because of the lack of capability in searching for specific resources, entrepreneurs are constrained in using market guanxi networks. Then, the embedded guanxi networks play a critical role in assisting enterprises to acquire needed resources in its early development period.

However, both embedded guanxi and market guanxi networks are import approaches for new enterprises to seize opportunities and obtain corresponding resources. These two strategic choices are complementary to each other, rather than substitutable. Considering the costs and gains, entrepreneurs usually put more weight on using one or the other. Embedded guanxi networks based on trust have advantages in long-term and low-cost transactions; but when taking the "human relationship" and "obligation" into consideration, enterprises may suffer much higher cost in maintaining embedded guanxi networks (Boist and Child, 1996), while market guanxi networks have no such burdens. As enterprises move to next stages of their development, they would try to exploit more market guanxi networks for necessary resources which can not otherwise obtained. In addition, a market guanxi network is more efficient than an embedded guanxi network in terms of capability development and resources.

H2a Enterprises tend to rely more on embedded guanxi networks at their early development stage and more on market guanxi networks at later development stages.

In addition to development stage, another important factor influencing enterprise behaviors and decisions is enterprise size (Nadler and Tushman, 1998). Previous studies on Chinese economy have concluded that entrepreneurial networks are vital to small and new enterprises' survival (Redding et al., 1990), and guanxi networks offset the shortage of necessary organizational capabilities needed to compete with large enterprises. However, small new enterprises have strategic and operational flexibility, and they pay more attention to cultivate guanxi networks to offset institutional and competitive disadvantages. On the other hand, the guanxi orientation in market environment forces the renqing (favor), mianzi (face-saving), and obligation to become latent regularities in China, within which people turn to members of their inner circle of friends and relatives to facilitate dealings (Punnert and Yu, 1990). Many private enterprises in China are built around this closely connected small circle consisting of family 
members or friends (Chen, 1994). Small enterprises can maintain flexibility and achieve higher effectiveness by "weaving and harvesting the guanxi network" (Pollock, 1991). As enterprise size increases, however, it becomes more difficult to have an entrepreneurial style of management because of the more complicated bureaucratic structures. In their seminal empirical works, Shan and Hamilton (1991) found that small enterprises are more likely to adopt a cooperative strategy than large enterprises. They also found that small enterprises utilize more resources in embedded guanxi networks, while large enterprises gain more access to capital and other needed resources and acquire more organization legitimacy from market guanxi networks. Furthermore, larger enterprises have accumulated more capability to cope with challenges in task environment, and easily manage exchanges in market guanxi networks.

H2b Small enterprises tend to utilize embedded guanxi networks more than medium and large enterprises, while medium and large enterprises tend to utilize market guanxi networks more than small enterprises.

\subsection{Embedded/Market Guanxi Networks and Entrepreneurial Growth}

Existing empirical studies have indicated that interpersonal connections based on trust and favor exert positive effects on enterprise performance in the context of China's transitional economy (Xin and Pearce, 1996; Peng and Luo, 2000; Luo, 2003; Li and Zhang, 2007). However, Guthrie (1998) argued that the impact of embedded guanxi on performance has weakened with the deepening of institutional transition and completing of legal regulatory system. In emerging economies, the importance of guanxi networks as a driver of enterprise performance is gradually substituted by the importance of competitive capabilities, which is independent of relationships and connections (Peng, 2002). Peng (2002) also found that, at their early development stage, enterprises are more likely to take network-based strategies due to immature institutional constraints, and shift to market-based strategies in later development phases. The limitation of such findings is that the different impact of various types of guanxi on enterprise performance has not been probed into, and the heterogeneous effects of Chinese culture on enterprise development still need to be further clarified.

At different stages of enterprise growth, embedded and market guanxi networks may present different patterns of impact on enterprise performance. Because of "liability of newness," entrepreneurs in the new enterprises have disadvantages in seizing opportunities, obtaining resources and cultivating capabilities for indentifying opportunities, improving product quality and organizing operations (Block \& MacMillan, 1985). To overcome such constraints, entrepreneurs sometimes utilize "asset parsimony" method to acquire resources, 
in order to promote enterprise growth at minimum cost (Starr et al., 1990). As the embedded guanxi networks are characterized by renqing, reciprocal, and obligation, entrepreneurs can seek key resources for enterprise growth through embedded guanxi network at a low cost (Cohen and Bradford, 1990). Therefore, entrepreneurs are more likely to rely on embedded guanxi networks at the early growth stage of their enterprises.

With the growth in enterprise age and size, the "liability of newness" of new enterprises diminishes, and the identity, legitimacy, and reputation gradually spread. The market guanxi networks become more important for enterprises (Starr et al., 1990). Meanwhile, embedded guanxi networks have their limitations due to the limited number of family members and friends in the network. Therefore, entrepreneurs would gradually turn to market guanxi networks (Peng, 2003). Thus, compared to embedded guanxi networks, market guanxi networks are more important for mature enterprises.

H3a As enterprise age increases, the importance of embedded guanxi networks to enterprise performance tends to decrease, while market guanxi networks tend to be more important.

H3b As enterprise size grows, the importance of embedded guanxi networks to enterprise performance tends to decrease, while market guanxi networks tend to be important.

\section{Research Method}

\subsection{Measurement}

An entrepreneur is the most important resource allocator in an enterprise, and his guanxi network is one of the most valuable assets for his/her enterprise, particularly at the early stage of enterprise development (Hite, 1999; Larson and Starr, 1993). At this stage, an entrepreneur's social network is, to a large degree, equal to his/her enterprise's social network (Bhide, 1999; Zaheer, McEvily, and Perrone, 1998). However, as an enterprise grows, it will gradually formalize and routinize its interpersonal networks (Bhide, 1999; Galaskiewicz and Zaheer, 1999; Larson and Starr, 1993; Zaheer et al., 1998). Under the Chinese context, entrepreneurs' interpersonal guanxi networks are always vital to the success of their enterprises, even if their enterprises' guanxi networks are formalized or routinized. In addition, entrepreneurial network contains most of their enterprises' inter-organizational network. Thus, it is appropriate to study enterprise behaviors from the perspective of entrepreneurial guanxi network.

Most entrepreneurs regard their guanxi network as confidential business secret and are therefore unwilling to report relevant information to researchers. We therefore adopted the measurement widely used in strategic studies and divided 
social networks into business and political networks (Peng and Luo, 2000; Luo, 2003; Moses, 2007; Li et al., 2008). The business networks are defined as entrepreneurial contacts with managers in other organizations, including suppliers, clients, and competitors; the political networks are specified as entrepreneurial contacts with officials in government department, guild, bank, industrial and commercial bureau, and tax bureau, etc. Considering the uniqueness of Chinese culture, this study divides entrepreneurial networks into family, shuren, and stranger guanxi networks. In measuring the strength of these networks, a simple 3-point Likert-type scale was used, with "1" standing for weak network ties (least frequently used) and "3" standing for strong network ties.

Particularly, self-reported return on assets (ROA) relative to competitors was used as a proxy for enterprises performance. Respondents were asked to estimate their enterprises' ROA compared with competitors on 5-point Likert scale ranging from "much less than our key competitors" to "much more than our key competitors." Since enterprise's size and age may exert different influences on organizational characteristics and performance (Wiklund and Shepherd, 2005), these items were include as control variables. The enterprise size was measured by the number of full-time employees, and age was calculated from the founding year reported by respondents.

\subsection{Sample and Data Collection}

The survey was conducted by the Research Center for Chinese Family Enterprise in Sun Yat-sen University. The center made a large scale survey on private enterprises in Guangdong province in 2007. During the investigation, a trial questionnaire was used for a pilot test in August, 2007, in which 45 valid questionnaires were returned. From September to December in 2007, the modified questionnaires were delivered to private enterprises in Shantou and Dongguan city, which have most developed private economies in China. Of the 570 distributed questionnaires, 447 were returned. 270 valid samples were selected according to the following criteria: (1) The respondent has worked in the current enterprises for no less than one year; (2) the respondent is either an entrepreneur or a senior manager; and (3) without invalid extreme answers. The detailed information about the research sample is show in Table 1 below:

\subsection{Data Analysis and Results}

\subsubsection{Common Methods Variance}

It should be noted that responses of the questionnaire survey were all obtained 
Table 1 Profile of the Sample

\begin{tabular}{llc}
\hline \multicolumn{1}{c}{ Item } & Information & Percentage (\%)/frequency \\
\hline \multirow{2}{*}{ Ownership } & Sole proprietorship & $29.9 \%$ \\
characteristics & Partnership enterprise & $6.4 \%$ \\
& Limited liability company & $63.7 \%$ \\
\hline \multirow{2}{*}{ Total assets (yuan) } & $\leqslant 5$ million & $51.4 \%$ \\
& $>5$ million & $48.6 \%$ \\
\hline \multirow{2}{*}{ No. of employee } & $<50$ & $28.5 \%$ \\
& $50-249$ & $43.8 \%$ \\
& $\geqslant 250$ & $27.7 \%$ \\
\multirow{2}{*}{ Location } & Shantou & 128 \\
& Dongguan & 142 \\
\hline
\end{tabular}

from a single source, and data on networks and other variables are therefore of the nature of self-reporting. Therefore, the common method variance problem should be dealt with. Following the suggestions of Podsakoff and Organ (1986), a single-factor test was undertaken as a reasonably post hoc remedial approach. Specifically, a principal components factor analysis was conducted on all of the 19 questionnaire measurement items. The unrotated factor solution output showed twelve factors with eigenvalues greater than one account for $69.99 \%$ of the total variance. In addition, the first factor only accounts for $31.74 \%$ of the total variance. In other words, there is no one "general" factor accounting for the majority of variance. Therefore, the problem of common method variance could be considered as not severe in this research.

\subsubsection{Comfirmatory Factor Analysis (CFA)}

In order to examine the liability and convergent validity of the network measurement models, CFA was performed by using the AMOS 5.0 software. The properties of this construct are showed in Table 2. The Cronbach's $\alpha$ of all kinds of network constructs are all above 0.50 , the critical value suggested by Hair et al. (1987). The fit indexes, including comparative fit index (CFI) and normed fit index (NFI), are all above the cutoff level of 0.90 (Bagozzi and Yi, 1988). The CFA results show that the measurement models have sound reliability and goodness of fit between the collected data and the theoretical factor structure.

To discern the different types of networks, the discriminant validity was tested by comparing the average variance extracted (AVE) of each construct to the square of correlations between this construct and others. Results are presented in Table 3. The comparison of AVE and corresponding squared correlations shows that the discriminant validity for each network construct is acceptable. 
Table 2 CFA of Networks Constructs

\begin{tabular}{|c|c|c|c|}
\hline Construct & Cronbach's $\alpha$ & Item & $\begin{array}{l}\text { Factor } \\
\text { loading }\end{array}$ \\
\hline \multirow{3}{*}{$\begin{array}{l}\text { Family guanxi in business } \\
\text { networks }\end{array}$} & \multirow{3}{*}{0.610} & Linkage with clients & $0.74^{* *}$ \\
\hline & & Linkage with suppliers & $0.74^{* *}$ \\
\hline & & Linkage with competitors & $0.57^{* *}$ \\
\hline \multirow{3}{*}{$\begin{array}{l}\text { Family guanxi in political } \\
\text { networks }\end{array}$} & \multirow{3}{*}{0.726} & $\begin{array}{l}\text { Linkage with officials in government } \\
\text { departments at different levels }\end{array}$ & $0.76^{* *}$ \\
\hline & & Linkage with officials in guild & $0.50^{* *}$ \\
\hline & & $\begin{array}{l}\text { Linkage with officials in bank, tax, } \\
\text { industrial and commercial bureaus }\end{array}$ & $0.85^{* *}$ \\
\hline \multirow{3}{*}{$\begin{array}{l}\text { Shuren guanxi in business } \\
\text { network }\end{array}$} & \multirow{3}{*}{0.566} & Linkage with clients & $0.69^{* *}$ \\
\hline & & Linkage with suppliers & $0.79^{* *}$ \\
\hline & & Linkage with competitors & $0.64^{* *}$ \\
\hline \multirow{3}{*}{$\begin{array}{l}\text { Shuren guanxi in political } \\
\text { network }\end{array}$} & \multirow{3}{*}{0.719} & $\begin{array}{l}\text { Linkage with officials in government } \\
\text { departments at different levels }\end{array}$ & $0.73^{* *}$ \\
\hline & & Linkage with officials in guild & $0.54^{* *}$ \\
\hline & & $\begin{array}{l}\text { Linkage with officials in bank, tax, } \\
\text { industrial and commercial bureaus }\end{array}$ & $0.77^{* *}$ \\
\hline \multirow{3}{*}{$\begin{array}{r}\text { Stranger guanxi in } \\
\text { business network }\end{array}$} & \multirow{3}{*}{0.727} & Linkage with clients & $0.56_{* *}^{* *}$ \\
\hline & & Linkage with suppliers & $0.60^{* *}$ \\
\hline & & Linkage with competitors & $0.65^{* *}$ \\
\hline \multirow{3}{*}{$\begin{array}{l}\text { Stranger guanxi in } \\
\text { political network }\end{array}$} & \multirow{3}{*}{0.897} & $\begin{array}{l}\text { Linkage with officials in government } \\
\text { departments at different levels }\end{array}$ & $0.91^{* *}$ \\
\hline & & Linkage with officials in guild & $0.82^{* *}$ \\
\hline & & $\begin{array}{l}\text { Linkage with officials in bank, tax, } \\
\text { industrial and commercial bureaus }\end{array}$ & $0.83^{* *}$ \\
\hline
\end{tabular}

Note: $N=270,{ }^{* *}$ indicates significant at 0.01 level.

Model 1 fit indices: $\chi^{2} / \mathrm{df}=231 / 116=1.99, \mathrm{CFI}=0.91, \mathrm{IFI}=0.91, \mathrm{NNFI}=0.86, \mathrm{RMSEA}=$ 0.06 .

Table 3 Discriminant Validity Test

\begin{tabular}{ccccccc}
\hline Construct & FRBN & FRPN & ARBN & ARPN & SRBN & SRPN \\
\hline FRBN & $(0.546)$ & & & & & \\
FRPN & 0.297 & $(0.502)$ & & & & \\
ARBN & 0.151 & 0.140 & $(0.566)$ & & & \\
ARPN & 0.078 & 0.268 & 0.272 & $(0.500)$ & & \\
SRBN & 0.220 & 0.176 & 0.223 & 0.116 & $(0.501)$ & \\
SRPN & 0.071 & 0.129 & 0.188 & 0.077 & 0.462 & $(0.500)$ \\
\hline
\end{tabular}

Note: AVEs are on the diagonal; Squared correlations are off-diagonal.

FRBN = Family guanxi in a business network, FRPN = Family guanxi in a political network, $\mathrm{ARBN}=$ shuren guanxi in a business network, ARPN = shuren guanxi in a political network enterprise performance, SRBN $=$ Stranger guanxi in a business network, SRPN $=$ Stranger guanxi in a political network. 


\subsubsection{Hypotheses Testing and Analysis}

Extant empirical studies on entrepreneurial networks have drawn contrasting conclusions on the impact of business and political networks on enterprise development (Peng and Luo, 2000; Li et al., 2008). This study adopts the hierarchical cluster analysis approach to test the above relationship and categorizes 18 measuring items ( 3 types of relationships $\times 6$ linkages). Based on the observed data's similarities and differences, cluster analysis provides a logical solution to validate the differences among these network constructs (Carter et al., 1994). The results presented in Table 4 show that all the linkages in stranger guanxi networks cluster as one class, while the linkages in familial and shuren guanxi cluster as another. There is no clear distinction between the familial and shuren guanxi. Therefore, it is reasonable to redefine the stranger guanxi as "market-guanxi networks", and combine the familial and shuren guanxi as "embedded-guanxi networks". Thus H1 is supported.

Table 4 Mean Differences between Market Guanxi and Embedded Guanxi Network $(N=$ 270)

\begin{tabular}{|c|c|c|c|c|}
\hline \multicolumn{2}{|c|}{ Type of enterprises } & \multicolumn{3}{|c|}{ Dependent variable } \\
\hline & & Business network & Political network & The whole network \\
\hline \multirow{3}{*}{ New enterprises } & Mean differences & $-0.078^{\dagger}$ & $-0.153^{*}$ & $-0.116^{*}$ \\
\hline & Standard error & 0.059 & 0.066 & 0.056 \\
\hline & Sig. & 0.055 & 0.023 & 0.025 \\
\hline \multirow{3}{*}{ "Old" enterprises } & Mean differences & $0.149^{*}$ & $0.121^{\dagger}$ & $0.135^{*}$ \\
\hline & Standard error & 0.063 & 0.070 & 0.060 \\
\hline & Sig. & 0.019 & 0.083 & 0.024 \\
\hline \multirow{3}{*}{ Small enterprises } & Mean differences & $-0.071^{*}$ & $-0.003^{\dagger}$ & $-0.037^{\dagger}$ \\
\hline & Standard error & 0.093 & 0.079 & 0.089 \\
\hline & Sig. & 0.048 & 0.098 & 0.070 \\
\hline \multirow{3}{*}{$\begin{array}{l}\text { Large and } \\
\text { medium-sized } \\
\text { enterprises }\end{array}$} & Mean differences & $0.219^{* *}$ & $0.230^{* *}$ & $0.225^{* *}$ \\
\hline & Standard error & 0.075 & 0.082 & 0.071 \\
\hline & Sig. & 0.004 & 0.005 & 0.002 \\
\hline
\end{tabular}

Further, MANOVA was adopted to analyze the differences between embedded-guanxi and market-guanxi networks. The sample was divided into groups according to enterprise age and size. 
In addition, hierarchical regression analysis was conducted to estimate the influence of the two networks on enterprise performance. In order to minimize collinearity, we used the mean-centered variables to create the interaction terms following the method proposed by Aiken and West (1991). The tolerances of independent variables are all above 0.6 (except the minimum value of 0.395 ). Thus, the problem of collinearity does not exist. The regression results are presented in Table 5. It shows that, among the different types of networks, only the shuren guanxi network exerts significant and positive impact on ROA, implying that the connections with officials in different government departments through the shuren guanxi network can improve enterprise performance, for the network helps enterprises gain more access to critical resources. In addition, the introduction of the interaction terms in Models 3 and 4 shows that only the "stranger guanxi network $\times$ age" interaction exerts positive influence on ROA: It supports, to some extent, the later part of the statements in H3a, i.e., the market-embedded guanxi networks become more critical as enterprise age increases. Table 6 shows the results of the testing hypotheses.

Table 5 Results of Hierarchical Regression Analysis $(N=270)$

\begin{tabular}{|c|c|c|c|c|}
\hline \multirow{2}{*}{ Variable } & \multicolumn{4}{|c|}{ ROA } \\
\hline & Model 1 & Model 2 & Model 3 & Model 4 \\
\hline \multicolumn{5}{|l|}{ Control variable } \\
\hline Age & 0.145 & 0.145 & 0.07 & 0.07 \\
\hline Size & 0.128 & 0.128 & 0.081 & 0.081 \\
\hline \multicolumn{5}{|l|}{ Independent variable } \\
\hline Family guanxi network & -0.091 & -0.091 & -0.040 & -0.040 \\
\hline Shuren guanxi network & $0.235^{*}$ & $0.235^{*}$ & $0.305^{* *}$ & $0.305^{* *}$ \\
\hline Stranger guanxi network & 0.089 & 0.089 & 0.003 & 0.003 \\
\hline \multicolumn{5}{|l|}{ Interaction term } \\
\hline Family guanxi network $\times$ size & & 0.094 & & 0.058 \\
\hline Shuren guanxi network $\times$ size & & 0.125 & & 0.075 \\
\hline Stranger guanxi network $\times$ size & & 0.143 & & 0.075 \\
\hline Family guanxi network $\times$ age & & & -0.032 & -0.032 \\
\hline Shuren guanxi network $\times$ age & & & 0.011 & 0.011 \\
\hline Stranger guanxi network $\times$ age & & & $0.195^{\dagger}$ & $0.195^{\dagger}$ \\
\hline \multicolumn{5}{|l|}{ Model fit index } \\
\hline$R^{2}$ & 0.046 & 0.046 & 0.07 & 0.07 \\
\hline Model $F$ & $5.906^{* *}$ & $5.906^{* *}$ & $4.845^{* *}$ & $4.845^{* *}$ \\
\hline$p\left(\Delta R^{2}\right)$ & 0.017 & 0.017 & 0.01 & 0.01 \\
\hline
\end{tabular}


Table 6 Results of the Testing Hypotheses

\begin{tabular}{|c|c|c|c|}
\hline Hypothesis & Content & Method & Result \\
\hline $\mathrm{H} 1$ & $\begin{array}{l}\text { In an entrepreneurial guanxi network, } \\
\text { family guanxi and shuren guanxi } \\
\text { constitute the main part of embedded } \\
\text { guanxi network, and stranger guanxi } \\
\text { constitutes the main part of market } \\
\text { guanxi network }\end{array}$ & Cluster analysis & Supported \\
\hline $\mathrm{H} 2 \mathrm{a}$ & $\begin{array}{l}\text { Enterprises tend to rely more on } \\
\text { embedded guanxi networks at their early } \\
\text { development stage and more on market } \\
\text { guanxi network at later development } \\
\text { stages }\end{array}$ & MANOVA & Supported \\
\hline $\mathrm{H} 2 \mathrm{~b}$ & $\begin{array}{l}\text { Small enterprises tend to utilize embedded } \\
\text { guanxi networks more than medium and } \\
\text { large enterprises, while medium and } \\
\text { large enterprises tend to utilize market } \\
\text { guanxi networks more than small } \\
\text { enterprises }\end{array}$ & MANOVA & Supported \\
\hline H3a & $\begin{array}{l}\text { As enterprise age increases, the } \\
\text { importance of embedded guanxi } \\
\text { networks to enterprise performance } \\
\text { tends to decrease, while market guanxi } \\
\text { networks tend to be more important }\end{array}$ & $\begin{array}{c}\text { Hierarchical } \\
\text { regression }\end{array}$ & $\begin{array}{l}\text { Partially } \\
\text { supported }\end{array}$ \\
\hline $\mathrm{H} 3 \mathrm{~b}$ & $\begin{array}{l}\text { As enterprise size grows, the importance } \\
\text { of embedded guanxi networks to } \\
\text { enterprise performance tends to } \\
\text { decrease, while market guanxi networks } \\
\text { tend to be important }\end{array}$ & $\begin{array}{l}\text { Hierarchical } \\
\text { regression }\end{array}$ & Not supported \\
\hline
\end{tabular}

\section{Discussion and Conclusion}

\subsection{Conclusion and Implication}

This study draws the following conclusions: (1) Family guanxi and shuren guanxi constitute the main part of the embedded guanxi network, and stranger guanxi constitutes the main part of market guanxi network, which indicate that the discussion of guanxi type and nature is both important and meaningful. (2) New or small enterprises tend to utilize embedded guanxi networks more than mature or large or middle sized enterprises, while the mature or large or middle sized enterprises tend to utilize market guanxi network more than the new or small enterprises, which indicate that as an enterprise grows in size and age, its reliance on embedded guanxi network decreases while its reliance on market guanxi network grows. (3) As an enterprise's age increases, the importance embedded guanxi networks to its performance does not decrease accordingly, while the importance of market guanxi network to its performance tend to grow, 
which indicate that the importance of the two types of guanxi networks to the enterprise performance varies according to the different development phases and enterprises shall balance them to maximize these networks' positive impact on enterprise performance.

This research fails to prove that the importance of embedded guanxi network to the enterprise performance tends to decrease as the enterprise age increases. The positive impact of embedded guanxi network on the enterprise performance remains significant throughout an enterprise's development. Possible reasons might include: (1) Although the economic transition has achieved tremendous progress in China in recent years, some of the social attitude, faith and value (for example, the family oriented approach and guanxi oriented approach to business), which are most important to Chinese culture, have remain to a large degree unchanged, and different types of "guanxi" still play important roles in Chinese people's daily life and business circle. (2) Chinese entrepreneurs highlight the importance of guanxi networks. Many entrepreneurs agreed in our survey that the market guanxi, which is of strategic significance to their enterprises, can be turned into shuren guanxi by guanxi operation to help their enterprises achieve stable and sustainable development. Our results demonstrate, to a certain degree, this dynamic change of guanxi network in theory. We also find no evidence showing that enterprise size has a moderating effect on the positive correlation between embedded-market guanxi network and enterprise performance.

\subsection{Contribution}

The contributions of this research are as follows: (1) It helps us to gain a deeper understanding of entrepreneurial/managerial networks. Previous researchers usually considered entrepreneurial/managerial networks homogeneous and treated them as a whole. However, this research points out the pattern of difference sequence of the entrepreneurial/managerial interpersonal relationships in the Chinese context and takes it as the basis of relationship classification. Moreover, this research employs the universal concepts of embeddability and marketability existing in the sociology and economics to separate the entrepreneurial/managerial interpersonal relationships into the embedded guanxi network and market guanxi network. This classification can be applied to other cultures as well as to Chinese culture. Therefore, this research renders a new prospective from which the studies on entrepreneurial/managerial networks can be conducted. (2) It has a significant implication to the guanxi research. As guanxi is an important phenomenon in Chinese society, a great amount of academic attention has been paid to guanxi. However, in most of relevant studies, guanxi is treated as a Chinese-style "special interpersonal connection." The current study argues that guanxi is not culture specific. Therefore, guanxi 
research shall not only concern about the cultural uniqueness, but also focus on constructing a culture-free guanxi theoretic system. In doing so, we need to combine viewpoints from sociology, economics, and management, or other relevant disciplines, as did in the current study.

\subsection{Discussion}

This research has a great practical meaning to enterprise strategic operation. Both guanxi itself and its cultural attribute are important to Chinese enterprises' operation and development. Our results show that both family guanxi based on blood relationship and shuren guanxi on the extension of family relationship play a key role in enterprise growth and development. In other words, the embedded guanxi network is vital to enterprise growth in China. However, as enterprises grow bigger and enter more new markets, they need to develop vigorously their market guanxi networks. This research reveals that, as an enterprise grows in age and size, both the frequency of utilization and strength of embedded guanxi networks tend to decline, while the importance of embedded guanxi networks to enterprise performance does not decrease accordingly: The positive correlation between the embedded guanxi network and enterprise performance remains positive all the time, regardless of enterprise age and size. By contrast, the frequency of utilization and strength of market guanxi networks increase as an enterprise grows in age, so does its impact on enterprise performance. It shows that under the Chinese context, if an enterprise wants to grow and develop, it must pay more attention to cultivation and development of market guanxi networks, and at the same time, bears the importance of embedded guanxi networks in mind. An enterprise needs to balance the two guanxi networks on the basis of its resource capacity.

However, in exploring the relationship between entrepreneurial/managerial networks and enterprise growth, this research does not take into consideration an enterprise's individualized attributes, such as resource capacity, ownership nature, industrial and market structure (e.g., competition intensity, public policy, structural change and degree of resources scarcity); secondly, this research fails to verify the intervening mechanism by which entrepreneurial/managerial networks influencing enterprise growth, such as opportunity identification, resource acquisition, resource development and integration and resource release. In addition, we did not adopt a longitudinal research design to collect empirical evidence on the change and evolution of entrepreneurial network. Therefore, further studies are needed to overcome these limitations and promote further our understanding of entrepreneurial network.

Acknowledgements This work is supported by the National Natural Science Foundation of 
China (No. 70872118, 70732005) and the "985 Project" of Sun Yat-sen University.

\section{References}

Acquaah M (2007). Managerial social capital, strategic orientation, and organizational performance in an emerging economy. Strategic Management Journal, 28: 1235-1255

Aiken L S, West S C (1991). Multiple Regression: Testing and Interpreting Interactions. Newbury Park, CA: Sage

Aldrich H E (1999). Organizations Evolving. London: Sage

Aldrich H E, Zimmer C (1986). Entrepreneurship through social networks, in: Sexton D, Smilor R (eds.), The Art and Science of Entrepreneurship. New York: Ballinger, 3-23

Bagozzi R P, Yi Y (1988). On the evaluation of structural equation model. Journal of Academy of Marketing Science, 16(1): 1-19

Barney J B, Clark D, Alvarez S (2003). Where does entrepreneurship come from? Network models of opportunity recognition and resource acquisition with application to the family enterprise. Paper presented at the Theories of the Family Enterprise Conference, University of Pennsylvania, Philadelphia

Bhide A (1999). The Origin and Evolution of New Businesses. Oxford: The Oxford University Press

Block Z, MacMillan I C (1985). Milestones for successful venture planning. Harvard Business Review, 63(5): 184-197

Boist M, Child J (1996). From fiefs to clans and network capitalism: Explaining china's emerging economic order. Administrative Science Quarterly, 41(4): 600-628

Carter N M, Stearns T M, Reynolds P D, Miller B A (1994). New venture strategies: Theory development with an empirical base. Strategic Management Journal, 15(1): 21-41

Chen M (1994). Guanxi and the Chinese art of network building. New Asia Review, (summer): $40-43$

Chhen A, Bradford D (1990). Influence without Authority. New York: John Wiley

Coleman J S (1990). Foundations of Social Theory. Cambridge, MA: Harvard University Press

Galaskiewicz J, Zaheer A (1999). Networks of competitive advantage, in: Bacharach SB (ed.), Research in the Sociology of Organizations, Vol. 16. Greenwich, CT: JAI Press, 237-262

Granovetter M S (1985). Economic action and social structure: The problem of embeddedness. American Journal of Sociology, 91: 481-510

Granovetter M S (1992). Problems of explanation in economic sociology, in: Nohria N, Eccles R (eds.), Networks and Organizations. Boston, MA: Harvard Business School Press, 25-56

Guthrie D (1998). The declining significance of guanxi in China's economic transition. The China Quarterly, 54: 254-282

Hair J F , Rolph E A, Ronald L T, William C B (1987). Multivariate Data Analysis with Readings, 3rd Edition. New York: Macmillam Publishing Company, 449

Hamilton G G (1991). Business network and economics development in east and southeast Asia. HongKong: Center for Asian Studies

Hite J M (1999). Embedded network ties in emerging entrepreneurial enterprises: Patterns, processes and paths. Doctoral dissertation, University of Utah, Salt Lake City, UT

Hite J M, Hesterly W (2001). The evolution of enterprise networks: From emergence to early growth of the enterprise. Strategic Management Journal, 22: 275-286

Larson A L, Starr J A (1993). A network model of organization formation. Entrepreneurship: Theory and Practice, 17(2): 5-15 
Li H, Atuahene-Gima K (2001). Product innovation strategy and the performance of new technology enterprises in China. Academy of Management Journal, 44(6): 1123-1134

Li H, Zhang Y (2007). The role of managers' political networking and functional experience in new enterprise performance: Evidence from China's transition economy. Strategic Management Journal, 28: 791-804

Li J, Poppo L, Zhou Z (2008). Do managerial ties in China always produce value? Competition, uncertainty, and domestic vs. foreign enterprises. Strategic Management Journal, 29: 383-400

Lovett S, Simmons L C, Raja K (1999). Guanxi versus the market: Ethics and efficiency. Journal of International Business Studies, 30: 2-28

Luo Y (2003). Industrial dynamics and managerial networking in an emerging market: The case of China. Strategic Management Journal, 24(13): 1315-1327

McEvily B, Marcus A (2005). Embedded ties and the acquisition of competitive capabilities. Strategic Management Journal, 26: 1033-1055

Montagu-Pollock M (1991). All the right connections. Asian Business, 27(1): 20-24

Nadler D A, Tushman M L (1988). Strategic Organizational Design. New York: HarperCollins

Nee V (1992). Organizational dynamics of market transition: Hybrid enterprises, property rights, and mixed economy in China. Administrative Science Quarterly, 31: 1-27

Park S H, Luo Y D (2001). Guanxi and organizational dynamics: Organizational networking in Chinese enterprises. Strategic Management Journal, 22: 455-477

Peng M W (2003). Institutional transitions and strategic choices. Academy of Management Review, 28: 275-296

Peng M W, Heath P S (1996). The growth of the enterprise in planned economies in transition: Institutions, organizations, and strategic choice. Academy of Management Review, 21(2): 492-528

Peng M W, Luo Y (2000). Managerial ties and enterprise performance in a transition economy: The nature of a micro-macro link. Academy of Management Journal, 43: 486-501

Podsakoff P M, Organ D W (1986). Self-reports in organizational research: Problems and prospects. Journal of Management, 12(4): 531-544

Portes A, Sensenbrenner J (1993). Embeddedness and immigration: Notes on the social determinants of economic action. American Journal of Sociology, 98(6): 1320-1350

Punnett B J, Yu P (1990). Attitudes toward doing business with the PRC. International Studies of Management and Organization, 20: 149-160

Redding S G (1990). The Spirit of Chinese Capitalism. Berlin: Walter de Gruyter

Ruef M, Aldrich H E, Carter N M (2002). Don't go to strangers: Homophily, strong ties, and isolation in the formation of organizational founding teams. American Sociological Association Meeting, Chicago, IL

Shan W, Hamilton W (1991). Country-specific advantage and international cooperation. Strategic Management Journal, 12(6): 419-432

Shanker M C, Astrachan J H (1996). Myths and realities: Family businesses' contribution to the U.S. economy. Family Business Review, 9(2): 107-119

Starr J A, MacMillan I A (1990). Resource cooptation via social contracting: Resource acquisition strategies for new enterprises. Strategic Management Journal, 11: 79-92

Uzzi B (1996). The sources and consequences of embeddedness for the economic performance of organizations: The network effect. American Sociological Review, 61: 674-698

Uzzi B (1997). Social structure and competition in interenterprise networks: The paradox of embeddedness. Administrative Science Quarterly, 42: 35-67

Uzzi B (1999). Embeddedness in the making of financial capital: How social relations and 
networks benefit enterprises seeking financing. American Sociological Review, 64: 481-505 Walker G, Kogut B, Shan W (1997). Social capital, structural holes and the formation of an industry network. Organization Science, 8: 109-125

Wiklund J, Shepherd D (2005). Entrepreneurial orientation and small business performance: A configurational approach. Journal of Business Venturing, 20: 71-91

Williamson O E (1991). Economic institutions: Spontaneous and intentional governance. Journal of Law, Economics and Organization, 7: 159-187

Williamson O E (1993). Calculativeness, trust, and economic organization. Journal of Law and Economics, 36: 453-586

Xin R, Pearce J L (1996). Guanxi: Connections as substitutes for formal institutional support. Academy of Management Journal, 39(6): 1641-1658

Yeung I Y, Tung R L (1996). Achieving business success in Confucian societies: The importance of guanxi (connection). Organizational Dynamics, 25(2): 54-65

Zaheer A, McEvily B, Perrone V (1998). Does trust matter? Exploring the effects of interorganizational and interpersonal trust on performance. Organization Science, 9(2): $141-159$

Zucker L (1986). Production of trust: Institutional sources of economic structure, in: Stam B M, Cummings L L (eds.), Research in Organizational Behavior, Vol. 8. Greenwich, CT: JAI Press, 53-101 